\title{
MODERN MAN \\ BETWEEN THE IMAGE OF GLORY AND FAKE IMAGES
}

\author{
Ștefan FLOREA ${ }^{*}$
}

\begin{abstract}
This paper wishes to be a Christian-Orthodox answer before the deleterious tendencies of the modern man, so much invoked by postmodernity. Appearing under different evolutionist, existentialist, hedonist, libertinism concepts or different slogans (such as "get religion out of school" or "we want hospitals, not cathedrals"), its final purpose is to deride God and to send Him in an enclosed space. Sitting on this prestigious pedestal, the modern man feels "free" to anchor himself, massively, into visibility, giving birth to a new diversity of idols that undermine dialogue and destroys transparency. In this vicious circle of the desire for excess of possession and objectual manipulation, for the contemporary man the ontological identity of "image of the Archetype" becomes rather discomfortable, embracing phantasms that are spiritually baneful. Thus, the universe in not perceived as a space destined to transfiguration through the liturgical acts, but as a good place to idolize and consume.
\end{abstract}

Keywords: liturgical acts, society, postmodernism, religious pluralism

Following thorough research of Christian faith teachings on creation of man, considered to be the coronal of the whole creation, we will see that this is the only rational being, which means that he has ontological capability, rendered by God through creation, to discern on his actions, even though they may be sometimes shadowed to the extent to which they turn into sins.

A meticulous look around us brings forth a painful ascertainment: the modern civilization has failed in the hideous; architectonical over-

PhD, Associate Professor, 'Valahia' University of Târgoviște (Faculty of Theology and Sciences of Education) Târgovişte, Romania. 
sizing of large metropoles, which make you think of the Babylonian and the hell, favors a way of life in which violence, immorality, consumption and pleasure exacerbation, eroticism and sodomy represent elements typical of the contemporary secularized society. This civilization moved the man's center of interest from God and faith to autonomous faculty of reasoning and science. Aloof from God, man has come to ignore the unspoken value and the authentic meaning of the world, attempting to impose through technique an artificial corrupt reasoning which matches his obvious intention to build, on his own, an earthly paradise. Therefore, remarks Christos Yanannaras: "what we call "progress" and «development» has proven to be a violation and destruction of nature, which represents a permanent death threat, including for the man"1. The environmental crisis caused by the irrational human behavior can find its answer only through transfiguration from the perspective of the divine revelation, which discloses the reasoning and the internal value of the world, its godly meaning.

Focused on the Holy Scripture and the Holy Fathers, the Orthodox Theology introduces the special intrinsic meaning of the creation, the world, because it does not reduce the grace and the matter in a dual manner, the grace pulses in the matter and this triggers the invitation to an encounter with spiritual beings: God and man. The nature, the creation is perceived as God's gift to man so that the latter may see nature, think of its Creator and search communion with Him. The world is God's gift to man whom He loved from the very beginning and to whom He freely entrusted the terrestrial paradise, expression of God's love in a metaphorical manner.

In its deep and straightforward meaning, the world has a different signification which man loses through his individualization because of the selfishness and the consequences of the lack of vertical and implicitly horizontal communication. The world seen and tailored by man bears a message which God sends man; it's the very God who turned into man for our deification. There is a God who searches man, who makes the encounter possible so that nature can become eternal.

${ }^{1}$ Christos YannNaras, Abecedar al Credinţei. Introducere în Teologia Ortodoxă (Elements of Faith. An Introduction to Orthodox Theology), București, E.I.B.M.B.O.R., 1996, p. 70. 
Man's mission and vocation in this world is deification. Being undoubtedly in God's own image, the human being finds in himself all elements of spiritual nature towards becoming the image of the divine Being.

Man was created following Christ's prototype ever since his paradisiacal state. This dignity, offered especially to man, means that he was from the very beginning created to enjoy an uninterrupted communion with God. His mind was free to go beyond sensitive reality of the world and to behold the godly realities. In his paradisiacal state, man was not attached to the world or led by his lust. And as long as this communion was maintained man enjoyed God's presence and a continuous potentially immortal existence.

However man decided on his own to look away from God and focused on him and the sensorial pleasures of the world. And this is how sin emerged as a detachment from beholding God, a kind of a desire to selfishly manifest one's self and to focus on the sensorial experience of the world. The result was a form of the body's captivity. Man chose what was within his reach - the physical and sensorial existence. We cannot deny that the corporality is natural to the human being, yet it was not the Creator's intention to place it in the center of the human being's attention. Instead of becoming a place for elevation towards deification - the body became the separation point between man and God, not because of the matter he was created from, but because of the matter turned into an idol. Man became permanent in the world and its pleasures; and once he estranged from his loving Creator, man discovered himself in shame, guilt, lust, idolatry, violence and death ${ }^{2}$.

Man - the being crated by God with the precise destination of sharing Divine Nature and becoming god by calling - is invited to achieve this vocation and to acquire resemblance of God. Man has a special value as he is created through a special act of God, so he is not only matter but also spirit which helps him to become an active interlocutor of God, through praying. His purpose here, in this world, in God's creation, is not selfishly targeted to himself, he is a priest of the whole creation and plays

2 Jurgen Moltmann, "Omul, chip al lui Dumnezeu şi drepturile omului” (Man, Face of God and Human Rights), in Studii teologice, no 5-10/1979, p. 633. 
the part of the creation's voice in the dialogue-prayer with God; moreover, his prayer becomes the prayer of the whole creation ${ }^{3}$.

This care taking of the creation arises from his mission to update the face and to lead it towards resemblance. By his actions man has to relate to the prototype by which he was created - being the image of God's Face (Colossians 1:15) - he has to offer himself to get to the "state of maturity, attaining to the whole measure of the fullness of Christ" (Ephesians 4:13).

Last but not least the orthodox anthropology has a strong christological character. There are therefore two models: Christ the prototype and the man "the image of God's Face" (Colossians 1:15). Thus perceived, the anthropology in the light of the Christological valences brings forth the fact that man is created in Christ's image, following the model of the nature which Christ - the new Adam, was to embrace and deify, His embodiment being the reason of all men's deification. The unique person of Christ, God-man, real God and real man, proves to be the meeting point between God and man, the connection between the world created and the divine existence. It is only on the basis of this connection that man may be restored, by Christ's divine-human model, and may get access to His liberating work (objective liberation) and its impropriation as a consequence and unification with Him through holy mysteries (subjective liberation). From an eschatological point of view, all Christians of all times have access to this intimate union with Christ, union through which $\mathrm{He}$ calls them towards becoming gods by vocation. This deification of the human nature is rather an overcoming of man's natural condition which cannot be attained unless two conditions are met: personal effort, man's struggle and the desire to be in communion with Christ ${ }^{4}$.

This mission of man is an evolution of ecclesiastical character and only inside an ecclesiastical community may man achieve his original mandate, because it is only inside an ecclesiastical community that man

${ }^{3}$ Dumitru STĂNILOAE, "Dinamica creaţiei în Biserică" (Dynamics of Creation in Church), in Ortodoxia, no. 3-4/1973, p. 280.

4 IDEM, "Sfầnta Treime şi creaţia lumii din nimic în timp" (Holy Trinity and Creation of World from Nothing in Time), in Mitropolia Olteniei, no. 2/1987, p. 46. 
may turn towards immortality and overcome life in death imprinted on him by his biological dimension at the time man became prone to fallibility. Therefore we see that the orthodox anthropology is strongly eschatology-oriented and favors a holistic vision on man and world from the perspective of creation restoration.

Image of God is the whole man, in all his life relations. In the fullness of his real life and in all relations of his life - economic, social, political and personal, man is determined to live before God, to answer God's Word and to make sure he attains God's face in the world. The face of God is highlighted in the relations of man with the other people. Man is God's image only in human communion with the other people. As long as man is real and acts humanly, he lives in a human life, in a world in which there is no hatred and love rules. This is the world of the full communion between man and his fellows. Yet, if man loses his humanity and sin emerges, man leaves the communion and becomes part of an inhumane world, a world of the sin in which man fails to attain God's image in him ${ }^{5}$.

Through theological virtues, faith, love and hope, man can regain his lost humanity and his dignity as a person can be restored. The same virtues help man to reestablish the eternal and deeply intimate with God, as virtues alone render man happy, be they separate or in the proximity of other goods. Using virtues enables the soul to be for the body what God is for the soul' ${ }^{6}$.

Man keeps communion with God and whole creation alive through prayers as well. Through prayers man entrusts his thoughts and things which such thoughts aim at: persons, things, states, etc. are offered to the Savior, and the Savior is called to come down among them ${ }^{7}$.

According to biblical references, man was created to glorify God and to enjoy the state of happiness in which he had been placed. After God's commandment was broken and man freely chose to sinfully disobey God, the sin of disobedience had repercussions on human nature. Consequently, there emerge two major issues. Firstly man's human nature

${ }^{5}$ Jurgen MoltmanN, quoted article, p. 633-634.

${ }^{6}$ Sfântul MAXIM Mărturisitorul, Ambigua, București, E.I.B.M.B.O.R., 2006, p. 253.

7 Panayotis Nellas, Omul animal îndumnezeit (Man - Deified Animal), Romanian translation by Ioan Ică Jr., Sibiu, Deisis, 2002, p. 96. 
was affected, because death - reward for the sin committed - was not an innate function of the nature - man had been created for life and not for death. Secondly this disorder affected the environment which became man's enemy. Aware of his helplessness and seeing himself tied more to the dust of earth of which he had been created than to the heaven to which he had been meant to belong, man became hostile to God. The sin of disobedience generated in its turn other acts of defiance in relation to God, in line with Saint Apostle Paul's words: "For I do not do the good I want to do, but the evil I do not want to do - this I keep on doing" (Romans 7:9).

Drifting apart from God and from obeying His commandments made man become more ambitious and shape his own opinions which most times concerned his own self. This man developed his own creed, an egoism which ignores problems and requirements of the others around him. This egoism isolates man in the society in which he lives and enables his to generate his own creed in his being and his self. This attitude is contrary to the evangelical principle of Christ who says that "The Son of God did not come to be served, but to serve and to give His life as a ransom for many" (Mark 10:45).

In his innate state man was in a perfect harmony with God, with external nature and himself. This is due to the fact that man was in a communion with God, his love, desire and thinking were directed to his Creator, and there was no obstacle between man and the environment which obeyed him. Man was growing and unifying with God and all his actions were heading for his Archetype. As remarked by priest Dumitru Popescu, "in his capacity of image of God's face in Trinity, man was not created to profane nature or to become nature's slave, but to live in communion with God and the entire creation through the power of the divine grace" $"$.

After falling into the sin, things change dramatically. The troubled union of man with his Creator seriously affects the human interpersonal relations as well as man's relations with the rest of the creation, with nature. His Holiness Patriarch Daniel said:

8 Dumitru PoPESCU, Iisus Hristos Pantocrator (Jesus Christ Pantocrator), București, E.I.B.M.B.O.R., 2005, p. 169. 
"The sinful man does not have the benefit of the gifts created by God in a state of thankfulness to Him, on the contrary he possesses them and spares himself of them to such an extent that he becomes their slave. The greater the man's deprivation of limited things, the weaker the communion between him and God the Gift-giver, the Unlimited One. His total addiction to limited creatures is visible in his worship of many kinds. The relation of the passionate man to his fellows and nature is no longer a relation of spiritual communion, but a possessive and conflictual relation. Man's focus on himself and the material world causes him to close before the work of the Spirit of God as Spirit of Communion. The selfish passions limit sinful man's freedom to limited actions to which he relates as to an ultimate reality".

Instituting the Eucharist during God's time in this world is tied to their committing with bread and wine, as matters of this world. With the power of His clerical and all praised body, God made them His Body and Blood. In line with God's words, the bread and the wine are His Body and Blood. "The bread and the wine are made, they absolutely and completely (limitlessly) become the liberating body and blood. Which means that the bread and the body are transposed, they become in a precise way, meaning not the matter, and not the abstract and allocative substance of this world (dust and ashes) which generally do not really exist, but the qualitative and determining type, kind, sort of this matter, namely the bread and the wine which, as elements of this world, remain unchanged and unaltered, yet they no longer belong to themselves or to this world, but to the all praised clerical body of Christ"10. "Come, for everything is ready now" (Luke 14, 17) is the voice of the Savior throughout centuries, constantly contemporized through the words spoken by the priest with every Holy Liturgy, calling, "inviting the Christians to the great love of God, which is offered to them through the communion of love between them: With fear of God and faith and love, draw near"11.

${ }^{9}$ DANIEL (Patriarch of the Romanian Orthodox Church), "Grijile vieţii şi libertatea sufletului credincios" (Life Worries and the Freedom of the Christian Soul), in Ziarul Lumina, 20.06.2012, p. 2.

10 Serghie Bulgakov, Dogma euharistică (The Eucharistic Dogma), Rom.transl. by Paraschiv Anghelescu, București, Paideia, 2000, p. 56.

11 Sorin CoSMA, "Sfânta Împărtăşanie în viaţa credincioşilor" (The Holy Eucharist in 
Through the holy liturgy Christians deign the real presence of Christ in the Holy Eucharist "not only on His Body and Blood, but also on His entire being as God-Man. The Savior Himself is present through the transformation of the gifts which means that the Eucharist is owed the same worship as is owed to His person" 12 .

Full communion with God is achieved through Eucharist just like full communion between Christians is achieved through the same Eucharist.

"The Eucharist unifies in the Body of Christ all those who attain and receive the sacrament through it. It unifies them because Christ brings everybody together so that He may offer them all as an offering to the heavenly Father and because they all receive Him as sacrament. They all meet in the same Body of Christ and they therefore form the extension of His Body. This is the reason why the Eucharist is the sacrament of unity, the Church is achieved and supported as Body of Christ through the Eucharist." $" 13$

Receiving the sacrament of his Body and Blood at the Last Supper, Christ commands his and apostles: "You all do this in remembrance of $m e$ " ( Luke 12, 19), showing them through this that He shall stand by them: "I am with you always to the very end of the age" (Matthew 28, 18), according to His promise, meaning that through the receipt of the Holy Eucharist, they will do exactly as $\mathrm{He}$ did at that time and they will be more than a commemoration of what happened then, yet He Himself shall stand by them and their successors. "Using the plural in "you all do this», Christ wants to tell us that this has to be done by the apostles and their successors, of the one hand, and that the Holy Eucharist has to be received in the middle of the community, similar to Christ who was surrounded by His disciples, of the other hand"14. To achieve communion between God and man as well as the communion between men, God gets them all in a place of worship; yet this is not enough. To achieve the real

Christians' Life), in Mitropolia Banatului, no. 4-6/1981, p. 327.

12 Gheorghe IsPAS, Euharistia - Taina unităţii Bisericii (The Eucharist - The Sacrament of the Church's Unity), București, Basilica, 2008, p. 75.

${ }^{13}$ Dumitru STĂNILOAE, "Din aspectul sacramental al Bisericii” (Of the Sacramental Aspect of the Church), in Studii teologice, no. 9-10/1996, p. 544.

${ }^{14}$ IDEM, "Biserica, locaş şi largă comuniune în Hristos" (Church, Place of Worship and Large Communion in Christ), in Ortodoxia, no.3/1982, p. 339. 
communion,

"God imprints on them His propensity to sacrifice because he who does not give himself up cannot achieve the real communion between him, God and the other people. And, as a place of worship, the church represents the point in which Christ brings everybody together in order to share with them His propensity for sacrifice through the receipt of the sacrament, i.e. receiving His Body and Blood" 15 .

Receiving the sacrament of the Christ, aserts fr. D. Stăniloae, "the separation between the members of the community disappears similarly to the separation between them and the other members of the other communities within which the same faith in Christ is confessed. All believers in all churches and of all times meet Christ who permanently offers Himself and they receive Him going therefore beyond the different times and the spaces of their sacrament"16.

Looking at all aspects of modern society, we can easily understand that a man's soul is continuously changing, searching to receive more and more, but the saddest - and we are aware of this - is that the Church no longer finds its place and is of no interest to man. This is exactly why the cult becomes a more formal, more superficial and even more deformed practice. All these negative effects have certain causes such as: the negative influence of the internet, of the television or mass media and because of this influence they are accused of indifference and immoral behavior.

A first issue the mankind has to cope with more and more often is individualism. This great vice of the contemporary society means nothing more than a promotion or an exaggerated capitalization of one's self. The world nowadays strongly attempts to surface this misbalance of mankind through the requirements of man to go higher and higher, be better and better at political, economic and cultural level. This is actually the sad denial of a religious belonging or of identity received by each man upon birth.

In reference to people, one has to admit that more and more people ignore the traditional values but are receptive and eager to embrace the

15 Ibidem, p. 342.

${ }^{16}$ Ibidem, p. 343. 
imported cultures. The growing desire to go up the social ladder or in a certain hierarchy or to earn more money ends up mastering the man and turning him into a slave who looks for nothing else but such "pleasures". Mastered by this issue of egoism and individualism, man will never be sensitive to his fellows' troubles and will always place his personal needs first. One should not hide behind the false impression that such challenge does not exist in reality and that young people actually pursue communion ${ }^{17}$. It would be great if this were true, yet the facts are much more serious. People are increasingly mastered by egoism, egocentrism and this leads to their separation from the surrounding world, each of them outlining their own cult which is more or less profound, a cult of their personality. And they are finally convinced that the others have to obey him.

In close connection with this challenge of individualism are consumerism and materialism. This issue may be understood as a current form of globalization, since it involves man's directing exclusively towards material, profit and income, namely the visible and the identifiable through senses. The more and more accelerated technological progress has led to a large production of goods and products which gave birth to a real world in which advertising, increasingly aggressive, has caused the emergence of the so called "society of consumption", society in which emphasis is no longer laid on really important things, but on how much people can consume, be they foods or mineral resources.

People nowadays are attacked more and more viciously by this challenge of society because, after 1989 , our country became very rapidly a country which consumes and no longer produces. Without knowing, people are caught in the toils of this sin and they may escape undamaged only through the salvation within the Church. All around us we see examples which make us realize that the abundance and the prosperity have become new values stimulating our society. Seeing such toxic examples everywhere, man comes to the conclusion that work can only be perfected through consumerism. The bigger the consumption, the bigger

17 Ionuţ POPA, "Problema familiei creştine astăzi. Pastoraţia copiilor, a tinerilor şi a bătrânilor" (The Issue of the Christian Family Today. The Church's Mission in relation to Children, Young People and Elders), in Ortodoxia, no. 4/2007, p. 124. 
the desire and the attempt to consume. It is never enough because the sweetness of this challenge is enormous. A consequence or result of this $\sin$ is the individualism we mentioned above.

A rather important issue which the modern man refuses to admit is the hedonist philosophy which starts to gain more and more popularity, especially among your people. This philosophy focuses on the pleasure and satisfaction in this life and represents the key purpose of the modern man.

Therefore, following a sincere and serious analysis, we fully agree that our youth today is profoundly anchored in this issue; the youth is, if we may say so, the largest consumer and challenger of pleasure. This feeling replaced other feelings, which are more efficient and longer-term, because this pleasure, be it inflicted by drugs or other noxious things, does not last forever. If we want such pleasure to bear full fruit we need to feed it on a regular basis. However, the physical pleasure, the palpable pleasure, the immediate pleasure and the pleasure without restrictions is gaining ground. It is difficult for the person who does not practice the orthodox culture to understand that it is preferable to pursue a pleasure and a joy which may be acquired only through removal of noxious things. To him pleasure without prohibition is more at handy and easier to achieve and does not require too many efforts on his part.

Maybe the most serious issue the modern man faces and which is the basis of everything highlighted above is globalization. This quite intensely debated and promoted phenomenon represent however an inevitable challenge. The conclusion is that we are not in the position to decide whether we want this process or we agree with it.

We are saying this because today "globalization simply exists, and we are somehow foredoomed to live with it, under its spectrum and to face it. What is or what does this phenomenon which we got used to calling globalization actually mean? It is impossible to exhaust all scopes of this reality in a single definition or formula" ${ }^{18}$.

In an attempt to summarize these issues, we can say that this

18 I. BARI, Probleme globale contemporane (Global Contemporary Issues), București, Economică Ph, 2003, p. 67. 
phenomenon of globalization represents a new very well defined and developed system, which came to replace another obsolete system and by this I mean the phenomenon of the Cold War which was the headlining ever since 1945. Throughout this globalization we have actually become one and on this basis came the principles which govern the current society, i.e. economic, cultural, political and, why not, the religious principles. None of the activities carried out these days are outside globalization.

"Globalization has become the symbol of our times. It is considered that the driving force which has directed the evolution of the world towards this point is the mirage of the free market capitalism with all its relating advantages. Integration into the mechanisms of this political and economic system in order to fully enjoy its benefits is a desideratum of all peoples which belong to the European culture and not only"19.

In other words, it represents globalization and universalization of certain specific phenomena.

Another idol of the contemporary man is the virtual reality. This net, into which people are more captured with every day that goes by, is rather difficult to untangle them out of and this is the mere consequence of the fact that they strongly refuse help. If we do the easy exercise of observing the reality around, we can see that people detach themselves from the surrounding reality and plunge more and more into the reality specially created for each of them by tablets, mobile phones and computers. We walk around and every day we see sad people, enclosed in a universe of their own. They forgot to smile and are worried about things which are out of the ordinary. Nevertheless this entire lethargy into which we are sinking every day suddenly changes when we hear a sound, a signal announcing a phone call or a text message or other tens and tens of likes. The most painful aspect is the fact that the face to face dialogue is replaced by online communication. People stopped communicating in joy and nostalgia, they settle for exchanges of cold and groundless replies.

"In the socializing places and the fast food restaurants, secondary

19 D. MARIN, Globalizarea şi aproximările ei (Globalization and its Approximations), București, Economică, 2004, p. 149. 
school pupils sit around tables and seem to communicate. Only seem: in fact, even though they sit one in front of the other, they all are absorbed by the screen of the mobile phone: they download pictures, exchange impressions on new Facebook 'friends'. Whenever they come out of the mirage of the virtual world for a few seconds they feel the need to take a picture of their encounter in the fast food restaurant which they are about to leave, picture which they immediately post on their account and write a comment in the section 'status': 'what are you thinking of? ', 'how are you feeling?' "20.

In terms of sexuality, we have to say that in a world deprived of love and mercy our insensitive society sells the maidenly purity of its virgin daughters in exchange for endless yearn for money and power. If we look at all the street billboards or watch any of the television series or catch a glimpse of the shelves in the supermarket, we will find it easy to understand what the number one product of the modern world is: the sex. Yet the sexuality does not sell by itself, it has to be combined with something else, from cigarettes and alcohol to dog food. The modern world has disfigured the image of the maiden and turned her into a debauchee. Under such circumstances, men have become lecherous and the entire morality of the human race has sunk into the abyss of a submankind. The virginity was once considered an essential virtue, yet today everything is upside down and it is considered a weakness.

Why is this so? Why did mankind fall into such state of depravation? This is certainly the result of the abolition of the divine image. "Instead of the divine, man started to worship the body and due to this deterioration, the meaning of love has grown vicious. The real love finds its meaning in the love revealed by God which is the perfect love"21. When man's mind and heart eliminate God, the love is lost. What is left is a garment underneath which man hides his lust.

The depth of the real love is so alienated of these times deprived of all sensitivity that it is chased away even in the rare cases in which love

${ }^{20}$ Ciprian VoICILĂ, Sub tirania virtualului şi a noilor tehnologii (Under the Tyranny of the Virtual and the New Technologies), at http://www.aparatorul.md/sub-tirania-virtualului-sia-noilor-tehnologii (accessed on 24.03.2017).

21 Teodor M. POPESCU, Meditaţii teologice (Theological Meditations), București, E.I.B.M.B.O.R., 1997, p. 89. 
happens to be experienced. This is in fact the masochism of love in our nihilistic world. To put it otherwise, we are so scared and hurt by false love that we find it difficult to accept a profound and unconditional love when we are offered such love.

The present society has various issues to fight and solve. We are referring here to the identity crisis, the acute crisis of values, the imitation by youth of all non-values promoted in mass media, the takeover of insipid 'models' or consumerism and accelerated secularization, blown out of proportion. The price that the society today is forced to pay is very high. Each social or age category pays an extremely high cost for these "nonvalues' which affect the world nowadays. The Orthodox Church's approach has to be rather therapeutic; the Church has to model the person into the idea of the kingdom through the Holy Mysteries and its entire activity. The pastoral activity of the Church in relation to people, in the present context dominated by globalization, will have to focus on this very modeling of the person, on the consolidation of the communion with them, on nurturing the consciousness of God's creatures, responsible for their own existence, of the people around them, as well as the entire creation. To the current society, marked by individualism, cultural-religious standardization, growing secularization, transient pleasures which attack human dignity, the Church offers the ecumenical model of the genuine unity in diversity, emphasizing the unique irreplaceable value of the human person, face of God called to be God's image, and preaches love as a fundamental structure of all inter-human references and relations. And, as priest Dumitru Stăniloae stated, "in the absence of this communion, the world is all sadness, ruin, destruction, massacres. If only people were eager to live in such love then they will experience eternal life"22.

\section{References}

1. BARI, I., Probleme globale contemporane (Global Contemporary Issues), București, Economică $\mathrm{Ph}, 2003$.

2. Bulgakov, Serghie, Dogma euharistică (The Eucharistic Dogma), rom.transl. by Paraschiv Anghelescu, București, Paideia, 2000.

22 Dumitru Stănilone, Mica Dogmatică vorbită. Dialoguri la Cernica (Little Spoken Dogmatic. Dialogues in Cernica), Sibiu, Deisis, 2007, p. 227. 
3. COSMA, Sorin, "Sfânta Împărtăşanie în viaţa credincioşilor (The Holy Eucharist in Christians' Life), in Mitropolia Banatului, no. 4-6/1981.

4. DANIEL (Patriarch of Romanian Orthodox Church), "Grijile vieţii şi libertatea sufletului credincios (Life Worries and the Freedom of the Christian Soul)", in Ziarul Lumina, 20.06.2012.

5. ISPAS, Gheorghe, Euharistia - Taina unitătii Bisericii (The Eucharist The Sacrament of the Church's Unity), București, Basilica, 2008.

6. ST. MAXIM MĂRTURISITORUL, Ambigua, București, E.I.B.M.B.O.R., 2006.

7. MARIN, D., Globalizarea şi aproximările ei (Globalization and its Approximations), București, Economică Ph, 2004.

8. Moltmann, Jurgen, "Omul, chip al lui Dumnezeu şi drepturile omului (Man, Face of God and Human Rights)", in Studii teologice, no. 510/1979.

9. Nellas, Panayotis, Omul animal îndumnezeit (Man - Deified Animal), rom.transl. by Ioan Ică Jr., Sibiu, Deisis, 2002.

10. POPA, Ionuţ, "Problema familiei creştine astăzi. Pastoraţia copiilor, a tinerilor şi a bătrânilor (The Issue of the Christian Family Today. The Church's Mission in relation to Children, Young People and Elders)", in Ortodoxia, no. 4/1997.

11. POPESCU, Dumitru, Iisus Hristos Pantocrator (Jesus Christ Pantocrator), București, E.I.B.M.B.O.R., 2005.

12. POPESCU, Teodor, M., Meditatii teologice (Theological Meditations), București, E.I.B.M.B.O.R., 1997.

13. StĂniloAe, Dumitru, "Biserica, locaş şi largă comuniune în Hristos (Church, Place of Worship and Large Communion in Christ)", in Ortodoxia, no.3/1982.

14. StĂNILOAE, Dumitru, "Din aspectul sacramental al Bisericii (Of the Sacramental Aspect of the Church)", in Studii teologice, no. 9-10/1996.

15. STĂNILOAE, Dumitru, "Dinamica creaţiei în Biserică (Dynamics of Creation in Church)", in Ortodoxia, no. 3-4/1979.

16. StĂNILOAE, Dumitru, "Sfânta Treime şi creaţia lumii din nimic în timp (Holy Trinity and Creation of World from Nothing in Time)", in Mitropolia Olteniei, no. 2/1987.

17. StăNILOAe, Dumitru, Mica Dogmatică vorbită. Dialoguri la Cernica (Little Dogmatic Spoken. Dialogues in Cernica), Sibiu, Deisis, 2007. 
18. Yannnaras, Christos, Abecedar al Credinţei. Introducere în Teologia Ortodoxã (Elements of Faith. An Introduction to Orthodox Theology), București, E.I.B.M.B.O.R., 1996.

\section{Web sources:}

19. VoICILĂ, Ciprian, Sub tirania virtualului şi a noilor tehnologii (Under the Tyranny of the Virtual and the New Technologies), in http://www.aparatorul.md/sub-tirania-virtualului-si-a-noilor-tehnologii/ (accessed on 24.03.2017). 